Nova Southeastern University

Florida

NOVA SOUTHEASTERN

UNIVERSITY

NSUWorks

Marine \& Environmental Sciences Faculty Articles Department of Marine and Environmental Sciences

$4-1-2002$

\title{
Fish Assemblages Associated with Artificial Reefs of Concrete Aggregates or Quarry Stone Offshore Miami Beach, Florida, USA
}

Brian K. Walker

Nova Southeastern University, walkerb@nova.edu

Bruce Henderson

Resources Management Division - Miami Beach

Richard E. Spieler

Nova Southeastern University, spielerr@nova.edu

Find out more information about Nova Southeastern University and the Halmos College of Natural Sciences and Oceanography.

Follow this and additional works at: https://nsuworks.nova.edu/occ_facarticles

Part of the Marine Biology Commons, and the Oceanography and Atmospheric Sciences and Meteorology Commons

\section{NSUWorks Citation}

Brian K. Walker, Bruce Henderson, and Richard E. Spieler. 2002. Fish Assemblages Associated with Artificial Reefs of Concrete Aggregates or Quarry Stone Offshore Miami Beach, Florida, USA .Aquatic Living Resources , (2) : 95 -105.

https://nsuworks.nova.edu/occ_facarticles/136.

This Article is brought to you for free and open access by the Department of Marine and Environmental Sciences at NSUWorks. It has been accepted for inclusion in Marine \& Environmental Sciences Faculty Articles by an authorized administrator of NSUWorks. For more information, please contact nsuworks@nova.edu. 


\title{
Fish assemblages associated with artificial reefs of concrete aggregates or quarry stone offshore Miami Beach, Florida, USA
}

\author{
Brian K. Walker ${ }^{\text {a, }}$ Bruce Henderson ${ }^{\text {b }}$, Richard E. Spieler ${ }^{\text {a,* }}$ \\ ${ }^{a}$ Oceanographic Center, Nova Southeastern University, 8000 North Ocean Drive, Dania FL, USA 33004 \\ ${ }^{\mathrm{b}}$ Resources Management Division, City of Miami Beach, 1700 Convention Center Drive, Miami Beach FL, USA 33139
}

Received 11 June 2001; accepted 17 January 2002

\begin{abstract}
Few studies have compared the suitability of different artificial reef construction materials in terms of their efficacy in acquiring diverse faunal assemblages. We compared the fishes associated with 12 co-located reefs constructed of limestone quarry boulders, concrete-gravel aggregate, or concrete-tire aggregate (four of each substrate) in $7 \mathrm{~m}$ of water, $200 \mathrm{~m}$ offshore Miami Beach, Florida, USA. All 12 reefs were deployed $100 \mathrm{~m}$ apart the same day in two lines of six. The four quarry stone reefs consist of a pile of 50 boulders each. The remaining eight reefs, of concrete-gravel aggregate and concrete-tire aggregate, were each constructed with $251.5 \mathrm{~m}$ edge and $251.2 \mathrm{~m}$ edge tetrahedron modules. Every two months from October 1998 to February 2001, SCUBA divers recorded fish species, abundance, and length, as well as spiny lobster, Panulirus argus, abundance. One hundred and forty-six species of fishes were recorded during the study period. The abundance and species richness of fish on each treatment exhibited a significant $(p<0.05)$ seasonal variation with summer months having the greatest numbers and winter the lowest. There was no significant difference in total fish or spiny lobster abundance or fish biomass amongst the three reef types $(p>0.05)$. Likewise, multi-dimensional scaling of Bray-Curtis dissimilarity indices did not indicate clustering of fish assemblages by reef type. Comparison of pre-deployment fish counts from the reef sites and neighboring hard bottom and jetty with counts from the same sites two years post-deployment indicate the artificial reefs increased both fish abundance and richness in the local area. (C) 2002 Ifremer/CNRS/Inra/IRD/Cemagref/Éditions scientifiques et médicales Elsevier SAS. All rights reserved.
\end{abstract}

\section{Résumé}

Assemblages de poissons associés à des récifs artificiels formés d'aggrégats en béton ou de pierres de carrière, au large de la plage de Miami, Floride, USA. Peu d'études ont comparé l'adéquation de différents matériaux pour la construction de récifs artificiels en termes d'efficacité à accueillir divers assemblages faunistiques. Nous comparons les poissons associés à 12 récifs construits de blocs de pierre calcaire de carrière, d'aggrégats en béton et graviers, ou d'aggrégats en béton et pneus (4 de chaque type de substrat) dans $7 \mathrm{~m}$ d'eau et à $200 \mathrm{~m}$ au large de la plage de Miami, Floride, Etats-Unis. Les 12 récifs ont été déployés à une distance de $100 \mathrm{~m}$ chacun et le même jour, alignés par groupe de 6 . Les quatre récifs en pierres de carrière consistent en l'empilement de 50 blocs chacun. Les huit récifs restants, d'aggrégats de béton-gravier et de pneu-béton ont chacun été construits de 25 modules tétraédriques de $1,5 \mathrm{~m}$ de côté et de 25 modules tétraédriques de 1,2 m de côté. Tous les deux mois, d'octobre 1998 à février 2001, des plongeurs ont noté les espèces de poissons, leur abondance, et leur taille, de même pour l'abondance des langoustes, Panulirus argus. Durant cette période, 146 espèces de poisson ont été observées. L'abondance et la richesse en espèces de chacun des types de récifs montrent une variation saisonnière significative $(p<0,05)$ entre les mois d'été, durant lesquels leurs nombres sont les plus élevés, et l'hiver, les plus faibles. Il n'y a pas de différence significative dans l'abondance totale ou la biomasse de poissons ou de langoustes entre les trois types de récifs $(p>0,05)$. De même, les indices de similarité pluri-dimensionnelle de Bray-Curtis n'indiquent pas de groupes d'assemblage de poissons par type de récifs. La comparison des comptages de poissons sur ce site, avant l'installation des récifs, ceux des fonds durs et ceux de la jetée, situés à proximité, avec les comptages, effectués deux ans après l'installation des récifs, montrent que les récifs artificiels ont permis, localement, l'augmentation à la fois de l'abondance et de la diversité des poissons. (c) 2002 Ifremer/CNRS/Inra/Cemagref/Éditions scientifiques et médicales Elsevier SAS. Tous droits réservés.

Keywords: Artificial reef; Fish; Panulirus argus

\footnotetext{
* Corresponding author.

E-mail address: spielerr@nova.edu (R.E. Spieler).
} 


\section{Introduction}

Interest in artificial reef habitats has greatly increased in the last few decades throughout the world CSeaman and Sprague, 1991: Stone et al. 1991; Seaman, 2000; Seaman and Jensen.2000) Countless types of artificial reefs made up of a variety of materials have been deployed worldwide. However, basic information is still lacking on floral and faunal interactions with the chemical composition and physical structure of these habitat materials CSeaman_and Sprague, 1991). Although substrate is listed as a primary controlling factor for optimal biological production on artificial reefs Gortone and Van Orman. 1985, limited studies have examined the suitability of materials for reef construction in terms of their efficacy in acquiring diverse flora or faunal assemblages Eitzhardinge and Bailey-Brock 1989: Anderson and Underwood 1994: Chin and Simmons. 1994: Gilliam et al. 1995: Henriquez et al. 1999: Miller and Barimo, 2001. Popular reef building materials include quarry rock, concrete and used automobile tires. Each of these materials has distinct advantages and disadvantages as reef building material. The physical and chemical differences among them could, in part, determine the faunal assemblages associated with the reefs.

Limestone and other quarry rock boulders are strong, stable, erosion resistant, cost-effective in many areas, and most closely resembles the natural calcium carbonate rock secreted from corals and other marine organisms. Moreover, the surface texture of the limestone boulder provides ample area and roughness for benthic flora and fauna to attach. However, quarry rock provides an improved marine habitat at the cost of destroying nearby terrestrial habitat from which the rock was excavated. Another potentially negative factor for quarry rock reefs is the limited ability to form the rock modules to specific design criteria, e.g. refuge size.

Concrete-gravel aggregate is presently considered to represent the most suitable cost-effective, man-made material for reef construction Fitzhardinge and Bailey-Brock. 1989: Anderson and Underwood. 1994: Chin and Simmons. 1994; Carr and Hixon, 1997). Concrete also has a chemical composition and texture very similar to coral Fitzhardinge and Bailey-Brock, 1989). Its weight and shapeable qualities allow for stable reef construction. Previous studies have found when comparing similar sized natural substrate (coral rock) and concrete, reef fish assemblages are nearly equal (Carr and Hixon, 1997. Concrete, however, has disadvantages as well; it does not recruit flora and fauna as well as natural substrate Fitzhardinge and Bailey-Brock, 1989). Concrete leaches out calcium hydroxide, or hydrated lime, which increases the alkalinity and $\mathrm{pH}$ of the surrounding seawater and this can differentially affect settlement of some organisms (Anderson, 1996. Concrete-gravel aggregates also have a limited life underwater due to such durability stresses as sulfate attack, leaching of lime, alkali-aggregate expansion, corrosion of embedded steel, and erosion from waves Guprenant, 1991.
Another man-made substrate deployed extensively in artificial reefs is used automobile tires Bohnsack and Sutherland, 1985: Meier and Eskridge, 1994; Murphey and Gregg.1994: Collins et al. 1999). Tire reefs are extremely durable Tolley 1981; they can be constructed in complex configurations Collins et al. 1999; they are easy to handle; and they are extremely cost effective (Eigley. 1994). However, if not bound and weighted properly tires lack stability and can become mobile underwater, scraping off natural substrate (Myatt et al.1989). Tires are also not as efficient as concrete or natural substrate for acquiring some invertebrates Downing et al. 1985; Eitzhardinge and BaileyBrock. 1989)] The negative recruitment of corals and other assemblages may relate to leachates exuded by the rubber surface Day et al_ 1993. Evans, 1997: Evans et al, 2000. Collins et al, 1999)

A concrete-tire aggregate has been suggested as an environmentally positive alternative to either the usual concrete-gravel aggregate or the use of entire tires for artificial reef construction Gilliam et al_1995. The concrete-tire aggregate, a patented, proprietary material, which may be used under license agreement, replaces a portion of gravel with chips of waste tires as part of the concrete aggregate. This aggregate remedies the ballast problem with the tire reefs and, given the surface of the reef is mostly concrete, invertebrates should recruit as with concrete-gravel aggregate reefs. In a preliminary study, Gilliam et al. (1995) previously compared two concrete-tire tetrahedron reefs with two concrete-gravel tetrahedron reefs of similar size and found no difference in fish species, total abundance, and invertebrate preference between the reefs.

We quantitatively compared the fish abundance, fish species richness, fish biomass, and spiny lobster, Panulirus argus abundance on two different artificial reef modules (boulder and tetrahedron), each constructed of one of three different materials: limestone, concrete-gravel aggregate, and concrete-tire aggregate. Our primary goal was to test the hypothesis, there is no difference in the total fish abundance, fish species, fish biomass, associated with these three reef construction materials. If the hypothesis is correct, similarly sized artificial reefs constructed of the differing substrates and placed in the same environment should acquire similar assemblages of fishes.

\section{Materials and methods}

\subsection{Experimental design}

To test the hypothesis of no difference in faunal associations between materials, 12 artificial reefs, four of each material: limestone, concrete-gravel aggregate, and concrete-tire aggregate, were deployed at a site located approximately $200 \mathrm{~m}$ offshore and $100 \mathrm{~m}$ north of Government Cut, Miami, Florida, USA in $7 \mathrm{~m}$ water depth (Fig. 1). The reefs, initially deployed June 18, 1998, are collocated in 


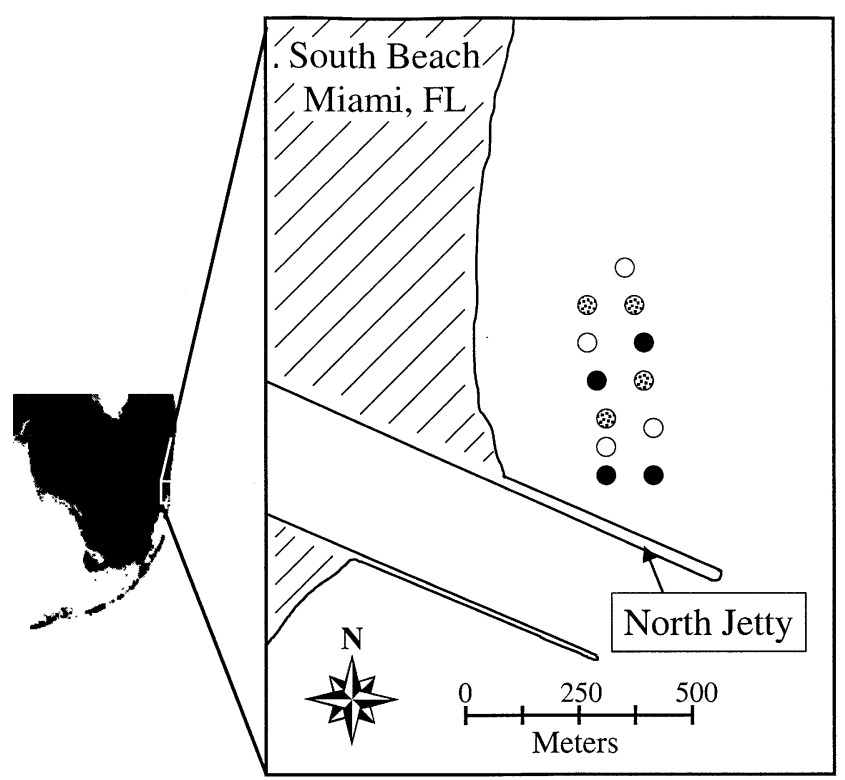

Fig. 1. Artificial reef array, $200 \mathrm{~m}$ offshore, and $100 \mathrm{~m}$ north of the entrance to Miami harbor (Government Cut). The reefs were constructed June 18, 1998 and are approximately $100 \mathrm{~m}$ apart in $7 \mathrm{~m}$ depth. Boulder reefs are depicted by filled circles, concrete-gravel reefs by patterned circles, and concrete-tire reefs by open circles. Reefs are not depicted to scale.

two lines of six, each reef separated from all others by approximately $100 \mathrm{~m}$ on a sandy bottom substrate with a few patches of hard bottom. Fish abundance, fish species, fish biomass, and lobster abundance were inventoried, during daylight, every two months on the 12 reefs for 28 months beginning in October 1998.

\subsection{Pre-deployment fish assessment}

Divers assessed the local fish populations in the immediate area by conducting pre-deployment surveys. On 12 May 1998, 24 stationary point-counts Bohnsack and Banherot. 1986) were conducted; twelve on the predetermined artificial reefs sites and twelve on the surrounding hard bottom. The point-count methodology consists of counting the fish in a $7.5 \mathrm{~m}$ radius imaginary cylinder from substrate to the surface Bohnsack and Bannerot 1986). A transect for fish abundance and species along the entire north side of the nearby north jetty rocks (Fig. 1) was also performed and the fish from substrate to surface were counted. In both pointcounts and transect the species, abundance, and total length were recorded. These initial surveys allowed for comparisons of the site, and the immediate surrounding area, preand post- reef deployment. The surveys were repeated on 26 May 2000. Recreational fishing and lobstering occurred on the artificial reefs and neighboring areas routinely during the study. No preference for a particular artificial reef or reef type was noted.

\subsection{Construction}

The four limestone reefs consist of $251.2 \mathrm{~m}$ and $251.5 \mathrm{~m}$ diameter boulders. The boulders were deployed by crane off a stationary barge held in place by a tugboat. The fifty boulders ( 25 of each size) were lowered off the side of the barge by the crane one site at a time and stacked into place by divers underwater. They were stacked in a two-layer configuration to help increase interstices and stability.

The concrete reefs, four of concrete-gravel aggregate and four of concrete-tire aggregate tetrahedrons, were produced by CSR Rinker under license agreement with Stability Reefs Inc. These also contain $251.5-\mathrm{m}$ edge and $251.2-\mathrm{m}$ edge modules. The concrete-gravel tetrahedrons were specifically made from dense mixtures, about $2093 \mathrm{~kg} . \mathrm{m}^{-3}$, of waste concrete with 1 to $2 \mathrm{~cm}$ gravel. The concrete-tire tetrahedrons were made the same way except tire chips were used in place of some of the gravel in the concrete mixture. The densities and gravel size varied slightly because the reefs were made from waste concrete, remains in a concretetruck after a construction job which is normally discarded in land fills. Because waste concrete was used, the cost of the tetrahedrons was approximately half the boulder cost per ton (\$12 versus \$22). Deployment costs was the same for all materials. An effort was made to construct all the reefs at least $100 \mathrm{~m}$ apart, to minimize movement of resident fishes from reef to reef, and to a similar size in height and width. The final configuration was completed in August 1998. A coded plastic tag was nailed to each reef for ease in underwater identification: boulder reefs-B1, B2, B3, B4; gravel-concrete reefs- $\mathrm{C} 1, \mathrm{C} 2, \mathrm{C} 3, \mathrm{C} 4$; tire-concrete reefsT1, T2, T3, T4.

\subsection{Post-deployment assessment}

The fish assemblages were determined by SCUBA divers using slates. Two divers, one fish counter and one safety diver, descended to the bottom a few meters off the reef. The fish counter then counted the fish (noting size, abundance, and species) within $1 \mathrm{~m}$ of the structure. Once all the fish were counted on the outside, the diver moved in to find all species within the reef and scanned the surfaces of the reef, looking for cryptic species. The fish species present, their abundance, and total length (TL) size class $(<2 \mathrm{~cm}, 2-5 \mathrm{~cm}$, $5-10 \mathrm{~cm}, 10-20 \mathrm{~cm}$, and $\geq 20 \mathrm{~cm}$ ) were recorded for each reef. Each reef count took approximately $20 \mathrm{~min}$ but was not time delimited. The size classes were later used to generate an estimate of fish biomass by a length to weight ratio. During the initial phase of fish counting, the safety diver stayed off the reef in close visual proximity to the fish counter. Mean horizontal visibility in the vicinity of the reefs normally exceeded $10 \mathrm{~m}$ but several times the counts were postponed due a visibility of less than $3 \mathrm{~m}$. After the fish counter moved onto the reef the safety diver moved in as well and counted spiny lobster, Panulirus argus. The 
reefs were small enough to allow for total populations to be assessed without subsampling and extrapolation.

\subsection{Statistical analysis}

Fish biomass was estimated using the fish length-weight relationship formula: $\log \mathrm{W}=\log \mathrm{a}+\mathrm{b} \log \mathrm{L}$, where $\log \mathrm{a}$ and $b$ are calculated for each species based on the slope of the linear regression line of $\log$ length vs. $\log$ weight described by Bohnsack and Harper (1998). With the exception of fish $\geq 20 \mathrm{~cm}$, the length of a fish in each size class was estimated to be the mean size of that class. For example, if a fish was in the $2<5 \mathrm{~cm}$ size class, then its length for the biomass formula was $3.5 \mathrm{~cm}$. In the $\geq 20 \mathrm{~cm}$ size class $20 \mathrm{~cm}$ was used for the estimated fish length. If a fish was not listed in the Bohnsack and Harper article, estimates were generated by numbers of the next closely related, similar sized fish.

Total fish abundance per reef (of each size class and all size classes combined), total fish species per reef, total fish biomass per reef, and total spiny lobster abundance were entered into a statistical program (Statistical Analysis Systems Inc., Cary, NC, USA) for analysis. The data were analyzed before and after scaling the data to reef size. The circumference measurement was used to calculate the radius of the reef by the formula $\mathrm{C}=2 \pi \mathrm{r}$. This radius, along with a maximum height measurement, was used in the formula for the volume of a cone, $V=1 / 3 \pi r^{2} h$. This volume was then divided into the abundance, richness, and biomass of fish and the abundance of lobster found on the reef to estimate each of these variables per $\mathrm{m}^{3}$. The data were not normally distributed and had high heteroscedasticty. Therefore we used a ranked (non-parametric) ANOVA (PROC RANK in SAS, Kruskal-Wallis test) and a StudentNewman-Keuls (SNK) test between means. In addition the Bray-Curtis dissimilarity index with multidimensional scaling (MDS) ordination was used Field_et al, 1982 to examine potential differences in fish-assemblage structure among the reefs. A $p$ value $<0.05$ in both ANOVA and SNK were accepted as a significant difference.

\section{Results}

\subsection{Construction}

Despite attempts to construct the reefs to similar size, the reefs ranged from 1.6 to $2.6 \mathrm{~m}$ (mean \pm standard error of the mean, SEM: $2.1 \pm 0.1 \mathrm{~m}$ ) in maximum height and 19.7 to $29.9 \mathrm{~m}$ (mean $24.2 \pm 0.8$ ) in maximum circumference.

\subsection{Abundance and biomass}

Fish assessment resulted in counts of 97826 total fish of 146 species (Table 1). There were no significant differences in total fish abundance (all censuses, species and size classes combined) amongst the three reef types (mean \pm SEM: boulders $641 \pm 71$ individuals per month, concrete-gravel $522 \pm 64$, concrete-tire $543 \pm 91 ; p>0.05$, ANOVA) (Fig. 2). There was also no significant difference between the reef types for total fish biomass (mean \pm SEM: boulder $21.2 \pm 3 \mathrm{~kg}$, concrete-gravel $18.1 \pm 4 \mathrm{~kg}$, concrete-tire $15.8 \pm 2 \mathrm{~kg} ; p>0.05$, ANOVA) or for the smaller size classes $(<10 \mathrm{~cm})(p>0.05$, ANOVA) regardless if the data was or was not scaled to reef size. Monthly mean total fish biomass, on all reefs combined, ranged from 12 to $38 \mathrm{~kg}$ for the first 12 months of study and from 5 to $34 \mathrm{~kg}$ for the second 12 months.

There were significant seasonal differences, all reefs combined, in fish abundance for each size class with the summer months (August and June of both years) having greater numbers than the winter months (April, December, and February of both years and October 1999) $(p<0.05$; ANOVA, SNK) (Fig. 2). Likewise, there were monthly differences across all reefs for fish biomass in each size class $(p<0.05)$. There were similar seasonal trends in the data for the $<10 \mathrm{~cm}$ size classes for both abundance and biomass. In general, the $<2 \mathrm{~cm}$ fish were most abundant in spring and early summer (April, June) the $2<5 \mathrm{~cm}$ fish were most abundant in middle to late summer (June, August), and the $5<10 \mathrm{~cm}$ fish were most abundant in late summer early autumn (August, October).

\subsection{Richness}

Unlike the fish abundance data, there was a significant difference in fish richness, the total number of species all size classes combined. Using raw data (not scaled to reef size) the boulder reefs appeared to have a significantly greater number of species than the concrete and tire tetrahedrons (mean: boulders $26 \pm 1$, concrete-gravel $22 \pm 1$, concrete-tire $23 \pm 1 ; P<0.05$, ANOVA) (Fig. 3). However when the data was scaled to reef size, it showed the boulders had a significantly lower number of species per $\mathrm{m}^{3}$ than the tetrahedrons reef $(p<0.05$, ANOVA, SNK). Due to this inconsistency, and because our volume calculations were an estimation of size, we examined potential differences in assemblage structure using a Bray-Curtis dissimilarity index with multidimensional scaling (MDS) ordination Field et al_ 1982 for summer (June and August, peak summer months for fish abundance and richness) as well as winter months (December and February). These analyses did not show any significant clustering of a particular reef type. In addition, no single species, which was represented on all replicates of a substrate, appeared to be restricted to a single reef type. A few fish were only found on one or two of the three substrates but these animals were rare in the census, not found on all the replicates of the substrate(s), and probably represent chance occurrence rather than preference. Significant seasonal differences were also noted in the 
Table 1

List of fishes recorded on the three artificial reef substrates over 28 months in mean abundance $/ \mathrm{m}^{3}$ of reef. A dash indicates none recorded on that reef type

\begin{tabular}{|c|c|c|c|c|}
\hline Common name & Scientific name & Boulder & Concrete & Tire \\
\hline Shark & Orectolobidae & & & \\
\hline Nurse shark & Ginglymostoma cirratum & 0.37 & 0.17 & 0.22 \\
\hline Guitarfish & Rhinobatidae & & & \\
\hline Atlantic guitarfish & Rhinobatos lentiginosus & 0.02 & - & - \\
\hline Stingray & Dasyatidae & & & \\
\hline Southern stingray & Dasyatis americana & 0.14 & 0.11 & 0.08 \\
\hline Yellow stingray & Urobatis jamaicensis & 0.20 & 0.07 & 0.20 \\
\hline Tarpon & Elopidae & & & \\
\hline Tarpon & Megalops atlanticus & 0.04 & 0.04 & 0.58 \\
\hline Moray eel & Muraenidae & & & \\
\hline Spotted moray & Gymnothorax moringa & 0.05 & - & - \\
\hline Purplemouth moray & Gymnothorax vicinus & 0.06 & 0.19 & 0.29 \\
\hline Sardine & Clupeidae & & & \\
\hline False Pilchard & Harengula clupeola & 0.05 & 2.20 & 36.35 \\
\hline Lizardfish & Synodontidae & & & \\
\hline Sand diver & Synodus intermedius & 0.03 & - & 0.10 \\
\hline Inshore lizardfish & Synodus foetens & - & - & 0.04 \\
\hline Batfish & Ogcocephalidae & & & \\
\hline Shortnose batfish & Ogcocephalus nasutus & 0.04 & - & - \\
\hline Polka-dot batfish & Ogcocephalus radiatus & 0.09 & - & - \\
\hline Squirrelfish & Holocentridae & & & \\
\hline Squirrelfish & Holocentrus adscensionis & 0.14 & 0.10 & 0.06 \\
\hline Pipefish & Syngnathidae & & & \\
\hline Pipefish & Syngnathus sp. & - & 0.03 & - \\
\hline Trumpetfish & Aulostomidae & & & \\
\hline Trumpetfish & Aulostomus maculatus & 0.28 & 0.07 & 0.31 \\
\hline Cornetfish & Fistulariidae & & & \\
\hline Bluespotted cornetfish & Fistularia tabacaria & 0.02 & - & - \\
\hline Sea bass & Serranidae & & & \\
\hline Black grouper & Mycteroperca bonaci & 0.06 & - & 0.29 \\
\hline Tiger grouper & Mycteroperca tigris & - & - & 0.03 \\
\hline Gag & Mycteroperca microlepis & 0.04 & - & - \\
\hline Red grouper & Epinephelus morio & 0.40 & 0.67 & 1.01 \\
\hline Graysby & Epinephelus cruentatus & 0.03 & - & 0.10 \\
\hline Rock hind & Epinephelus adscensionis & - & 0.04 & - \\
\hline Scamp & Mycteroperca phenax & 0.02 & 0.04 & - \\
\hline Sand perch & Diplectrum formosum & 0.13 & 0.24 & 0.28 \\
\hline Butter hamlet & Hypoplectrus unicolor & 0.02 & 0.04 & - \\
\hline Belted sandfish & Serranus subligarius & 0.03 & - & - \\
\hline Cardinalfish & Apogonidae & & & \\
\hline Flamefish & Apogon maculatus & 0.05 & 0.23 & 0.48 \\
\hline Barred cardinalfish & Apogon binotatus & - & 0.14 & 0.05 \\
\hline Twospot cardinalfish & Apogon pseudomaculatus & 0.03 & 0.24 & 0.54 \\
\hline Remora & Echeneidae & & & \\
\hline Sharksucker & Echeneis naucrates & 0.03 & - & 0.07 \\
\hline Cobia & Rachycentridae & & & \\
\hline Cobia & Rachycentron canadum & - & - & 0.03 \\
\hline Jack & Carangidae & & & \\
\hline Round scad & Decapterus punctatus & 7.89 & 19.44 & 35.08 \\
\hline Mackerel scad & Decapterus macarellus & 4.59 & 3.0 & 0.03 \\
\hline Amberjack & Seriola dumerili & 0.82 & 0.31 & 1.41 \\
\hline Blue runner & Caranx crysos & 2.66 & 4.90 & 2.62 \\
\hline Bar jack & Caranx ruber & 1.62 & 1.68 & 3.28 \\
\hline Yellow jack & Caranx bartholomaei & 2.90 & 2.92 & 2.22 \\
\hline Leatherjacket & Oligoplites saurus & 0.05 & 0.16 & 0.78 \\
\hline Snapper & Lutjanidae & & & \\
\hline Yellowtail snapper & Ocyurus chrysurus & 0.81 & 0.87 & 0.78 \\
\hline Mahogany snapper & Lutjanus mahogoni & - & 0.40 & - \\
\hline Gray snapper & Lutjanus griseus & 19.91 & 20.97 & 23.13 \\
\hline Lane snapper & Lutjanus synagris & 7.20 & 6.45 & 4.85 \\
\hline Dog snapper & Lutjanus jocu & - & 0.16 & - \\
\hline Mutton snapper & Lutjanus analis & - & - & 0.09 \\
\hline Schoolmaster & Lutjanus apodus & 0.12 & 0.08 & 0.05 \\
\hline
\end{tabular}


Table 1. (Continued).

List of fishes recorded on the three artificial reef substrates over 28 months in mean abundance $/ \mathrm{m}^{3}$ of reef. A dash indicates none recorded on that reef type

\begin{tabular}{|c|c|c|c|c|}
\hline Common name & Scientific name & Boulder & Concrete & Tire \\
\hline Mojarra & Gerreidae & & & \\
\hline Yellowfin mojarra & Gerres cinereus & 0.31 & 0.72 & 0.05 \\
\hline Slender mojarra & Eucinostomus jonesi & - & 0.04 & - \\
\hline Grunt & Haemulidae & & & \\
\hline Cottonwick & Haemulon melanurum & 0.05 & 0.15 & 0.03 \\
\hline White grunt & Haemulon plumieri & 24.81 & 37.12 & 28.39 \\
\hline Tomtate & Haemulon aurolineatum & 491.1 & 559.9 & 402.8 \\
\hline Margate & Haemulon album & 0.68 & 0.25 & 0.21 \\
\hline French grunt & Haemulon flavolineatum & 2.35 & 6.53 & 4.09 \\
\hline Spanish grunt & Haemulon macrostomum & 0.34 & - & 0.09 \\
\hline Bluestripe grunt & Haemulon sciurus & 24.29 & 6.41 & 17.85 \\
\hline Striped grunt & Haemulon striatum & 2.73 & 3.14 & 0.03 \\
\hline Sailors choice & Haemulon parrai & 0.51 & 0.55 & 0.38 \\
\hline Smallmouth grunt & Haemulon chrysargyreum & 0.38 & 0.19 & 2.48 \\
\hline Black margate & Anisotremus surinamensis & 0.26 & 0.24 & 0.40 \\
\hline Porkfish & Anisotremus virginicus & 15.25 & 20.44 & 21.58 \\
\hline Pigfish & Orthopristis chrysoptera & 14.86 & 36.89 & 38.11 \\
\hline Ceasar grunt & Haemulon carbonarium & 0.13 & - & 0.03 \\
\hline Porgy & Sparidae & & & \\
\hline Pinfish & Lagodon rhomboides & 3.74 & 1.43 & 1.70 \\
\hline Spottail pinfish & Diplodus holbrooki & 0.09 & 0.10 & 0.03 \\
\hline Sea bream & Archosargus rhomboidalis & 0.30 & 0.35 & 1.42 \\
\hline Sheepshead & Archosargus probatocephalus & 0.02 & 0.04 & 0.11 \\
\hline Saucereye porgy & Calamus calamus & 0.12 & 0.12 & 0.21 \\
\hline Sheepshead porgy & Calamus penna & 0.07 & 0.08 & 0.07 \\
\hline Drum & Sciaenidae & & & \\
\hline Highhat & Equetus acuminatus & 3.28 & 1.32 & 2.23 \\
\hline Reef croaker & Odontoscion dentex & 0.46 & - & 0.03 \\
\hline Cubbyu & Equetus umbrosus & - & 0.06 & - \\
\hline Jacknifefish & Equetus lanceolatus & 0.02 & - & 0.03 \\
\hline Sweeper & Pempheridae & & & \\
\hline Glassy sweeper & Pempheris schomburgki & 0.56 & 0.87 & 0.06 \\
\hline Goatfish & Mullidae & & & \\
\hline Spotted goatfish & Pseudupeneus maculatus & 1.04 & 0.25 & 0.08 \\
\hline Yellow goatfish & Mulloidichthys martinicus & 1.15 & 0.46 & 0.72 \\
\hline Sea chub & Kyphosidae & & & \\
\hline Bermuda chub & Kyphosus sectatrix & 0.27 & - & 0.11 \\
\hline Butterflyfish & Chaetodontidae & & & \\
\hline Spotfin butterflyfish & Chaetodon ocellatus & 0.34 & 0.13 & 0.27 \\
\hline Banded butterflyfish & Chaetodon striatus & 0.04 & - & - \\
\hline Reef butterflyfish & Chaetodon sedentarius & 0.03 & 0.08 & 0.12 \\
\hline Foureye butterflyfish & Chaetodon capistratus & 0.03 & - & 0.04 \\
\hline Angelfish & Pomacanthidae & & & \\
\hline Queen angelfish & Holacanthus ciliaris & 0.22 & 0.13 & 0.04 \\
\hline Blue angelfish & Holacanthus bermudensis & 0.17 & 0.20 & 0.09 \\
\hline French angelfish & Pomacanthus paru & 0.14 & 0.03 & 0.13 \\
\hline Gray angelfish & Pomacanthus arcuatus & 0.04 & 0.19 & 0.16 \\
\hline Damselfish & Pomacentridae & & & \\
\hline Sergeant major & Abudefduf saxatilis & 0.78 & 1.44 & 0.98 \\
\hline Dusky damselfish & Stegastes dorsopunicans & 3.07 & 2.77 & 2.47 \\
\hline Threespot damselfish & Stegastes planifrons & 0.36 & 0.60 & 0.14 \\
\hline Beaugregory & Stegastes leucostictus & 2.23 & 2.94 & 2.19 \\
\hline Bicolor damselfish & Stegastes partitus & 0.27 & 0.62 & 1.19 \\
\hline Cocoa damselfish & Stegastes variabilis & 5.83 & 4.91 & 4.67 \\
\hline Longfin damselfish & Stegastes diencaeus & 0.26 & 0.33 & 0.21 \\
\hline Sunshinefish & Chromis insolatus & - & - & 0.10 \\
\hline Wrasse & Labridae & & & \\
\hline Hogfish & Lachnolaimus maximus & 0.41 & 0.61 & 0.83 \\
\hline Spotfin hogfish & Bodinatus pulchellus & - & 0.04 & - \\
\hline Spanish hogfish & Bodianus rufus & 0.20 & 0.51 & 0.09 \\
\hline Green razorfish & Xyrichthys splendens & 0.07 & 0.04 & - \\
\hline Clown wrasse & Halichoeres maculipinna & 0.05 & 0.04 & 1.91 \\
\hline Slippery dick & Halichoeres bivittatus & 6.42 & 12.49 & 10.85 \\
\hline Yellowcheek wrasse & Halichoeres cyanocephalus & - & - & 0.08 \\
\hline
\end{tabular}


Table 1. (Continued).

List of fishes recorded on the three artificial reef substrates over 28 months in mean abundance $/ \mathrm{m}^{3}$ of reef. A dash indicates none recorded on that reef type

\begin{tabular}{|c|c|c|c|c|}
\hline Common name & Scientific name & Boulder & Concrete & Tire \\
\hline Puddingwife & Halichoeres radiatus & 0.45 & 1.07 & 0.56 \\
\hline Bluehead wrasse & Thalassoma bifasciatum & 1.59 & 2.16 & 2.04 \\
\hline Parrotfish & Scaridae & & & \\
\hline Striped parrotfish & Scarus iserti & 0.47 & 0.16 & 1.12 \\
\hline Rainbow parrrotfish & Scarus guacamaia & 0.03 & 0.04 & 0.09 \\
\hline Bucktooth parrotfish & Sparisoma radians & 0.11 & 0.04 & 0.77 \\
\hline Red tail parrotfish & Sparisoma chrysopterum & 1.36 & 0.63 & 0.30 \\
\hline Redfin parrotfish & Sparisoma rubripinne & 0.79 & 0.10 & 0.18 \\
\hline Greenblotch parrotfish & Sparisoma atomarium & 0.25 & 0.31 & 0.81 \\
\hline Stoplight parrotfish & Sparisoma viride & 3.26 & 3.52 & 4.79 \\
\hline Redband parrotfish & Sparisoma aurofrenatum & 3.07 & 1.69 & 3.46 \\
\hline Bluelip parrotfish & Cryptotomus roseus & - & - & 0.16 \\
\hline Combtooth blenny & Blennidae & & & \\
\hline Molly miller & Scartella cristata & - & 0.03 & - \\
\hline Redlip blenny & Ophioblennius atlanticus & - & - & 0.05 \\
\hline Hairy blenny & Labrisomиs nисhipinnis & 0.02 & - & 0.05 \\
\hline Downy blenny & Labrisomus kalisherae & - & 0.03 & - \\
\hline Barred blenny & Hypleurochilus bermudensis & 0.21 & 0.08 & 0.15 \\
\hline Seaweed blenny & Parablennius marmoreus & 1.13 & 1.38 & 1.50 \\
\hline Saddled blenny & Malacoctenus triangulatus & - & 0.24 & 0.16 \\
\hline Rosy blenny & Malacoctenus macrops & 0.06 & 0.11 & 0.17 \\
\hline Roughhead blenny & Acanthemblemaria aspera & 0.02 & - & - \\
\hline Marbled blenny & Paraclinus marmoratus & - & - & 0.10 \\
\hline Wrasse blenny & Hemiemblemaria simulus & - & - & 0.05 \\
\hline Goby & Gobiidae & & & \\
\hline Neon goby & Gobiosoma oceanops & 0.28 & 0.06 & 0.07 \\
\hline Bridled goby & Coryphopterus glaucofraenum & 1.39 & 2.29 & 1.96 \\
\hline Glass/Masked goby & Coryphopterus sp. & 0.23 & 0.26 & 0.08 \\
\hline Tiger goby & Gobiosoma macrodon & 0.32 & 0.19 & 0.61 \\
\hline Blue goby & Ioglossus calliurus & - & 0.10 & - \\
\hline Pallid goby & Coryphopterus eidolon & 0.05 & - & - \\
\hline Spadefish & Ephippidae & & & \\
\hline Spadefish & Chaetodipterus faber & - & 0.04 & 0.03 \\
\hline Surgeonfish & Acanthuridae & & & \\
\hline Ocean surgeon & Acanthurus bahianus & 2.48 & 2.79 & 2.67 \\
\hline Doctorfish & Acanthurus chirurgus & 3.54 & 5.36 & 6.85 \\
\hline Blue tang & Acanthurus coeruleus & 1.77 & 3.76 & 2.75 \\
\hline Barracuda & Sphyaenidae & & & \\
\hline Barracuda & Sphyraena barracuda & 0.04 & 0.07 & 0.07 \\
\hline Mackerel and tuna & Scombridae & & & \\
\hline Cero & Scomberomorus regalis & - & - & 0.05 \\
\hline Scorpionfish & Scorpaenidae & & & \\
\hline Spotted scorpionfish & Scorpaena plumieri & 0.52 & 0.11 & 0.24 \\
\hline Leatherjacket & Balistidae & & & \\
\hline Scrawled filefish & Aluterus scriptus & 0.03 & 0.12 & 0.11 \\
\hline Orangespotted filefish & Cantherhines pullus & 0.07 & - & 0.03 \\
\hline Planehead filefish & Monacanthus hispidus & 0.40 & 0.21 & 0.08 \\
\hline Gray trigger & Balistes capriscus & 3.09 & 3.54 & 5.55 \\
\hline Boxfish & Ostraciidae & & & \\
\hline Scrawled cowfish & Lactophrys quadricornis & 0.71 & 0.26 & 1.03 \\
\hline Spotted trunkfish & Lactophrys trigonus & 0.05 & - & - \\
\hline Honeycomb cowfish & Lactophrys polygonia & 0.02 & 0.04 & - \\
\hline Smooth trunkfish & Lactophrys triqueter & 0.04 & 0.06 & 0.03 \\
\hline Puffer & Tetraodontidae & & & \\
\hline Sharpnose puffer & Canthigaster rostrata & 0.34 & 0.19 & 0.75 \\
\hline Bandtail puffer & Sphoeroides spengleri & 0.18 & 0.21 & 0.19 \\
\hline Spiny puffer & Diodontidae & & & \\
\hline Porcupinefish & Diodon hystrix & 0.40 & 0.52 & 0.54 \\
\hline Balloonfish & Diodon holocanthus & 0.12 & 0.11 & 0.12 \\
\hline Spotted burrfish & Chilomycterus atinga & 0.14 & - & 0.08 \\
\hline Total species present: 146 & Total species present per treatment & 123 & 111 & 122 \\
\hline
\end{tabular}




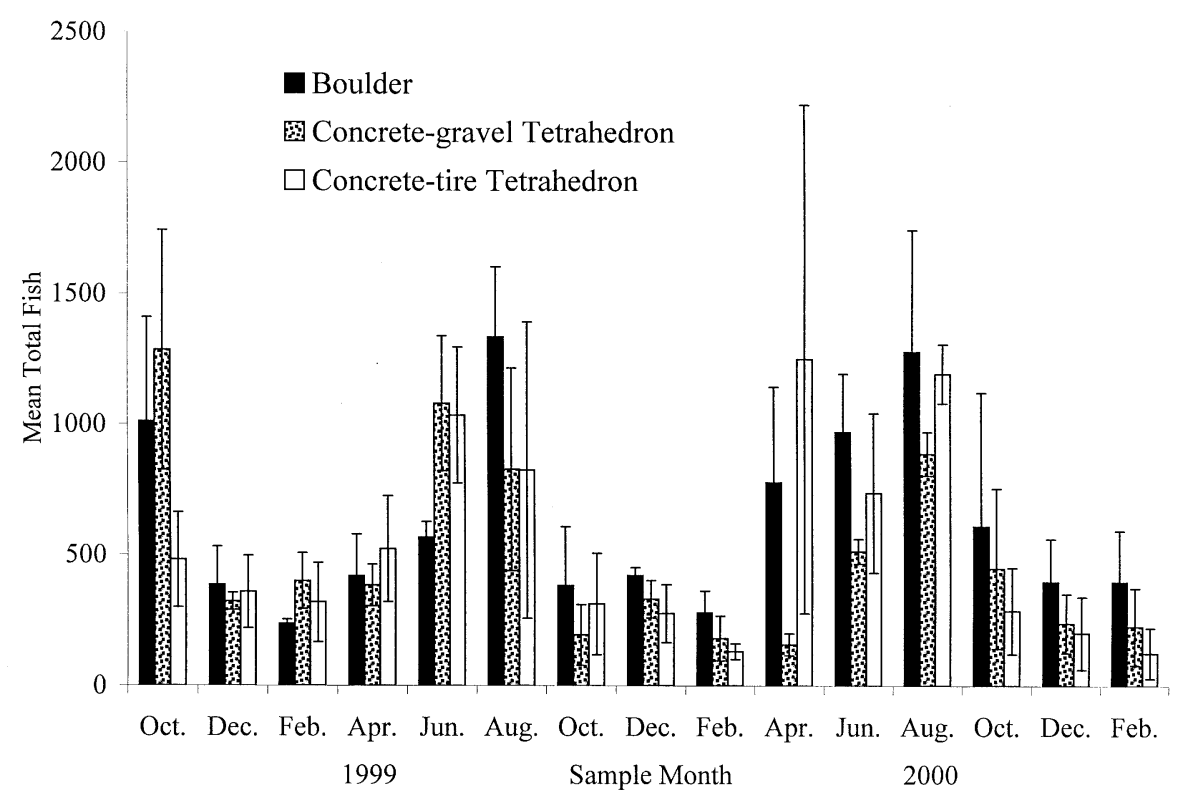

Fig. 2. Mean fish abundance (all species of all sizes combined) on boulder, concrete-gravel, or concrete-tire reefs by month. Vertical lines represent one standard error of the mean.

species data. There were significantly more species on all the reefs in the summer months than the winter months (Fig. 3). The highest numbers of fish and of species of fish were counted in June, August, and October. Spiny lobster abundance did not differ among reef types or seasonally (mean: boulders $16 \pm 3$ individuals, gravel-concrete $16 \pm 3$, tireconcrete $14 \pm 3$; $P>0.05$, ANOVA) (Fig. 4).

\subsection{Pre and post deployment abundance and richness}

Pre- and post-deployment hard bottom point counts were statistically different $(P<0.05$, Student's $t$-test) with a mean $5 \pm 1.4$ total fish per count pre-deployment versus a mean of $40.6 \pm 10.1$ fish post-deployment. Species richness showed similar significance with a pre-deployment mean of $1.8 \pm 0.3$

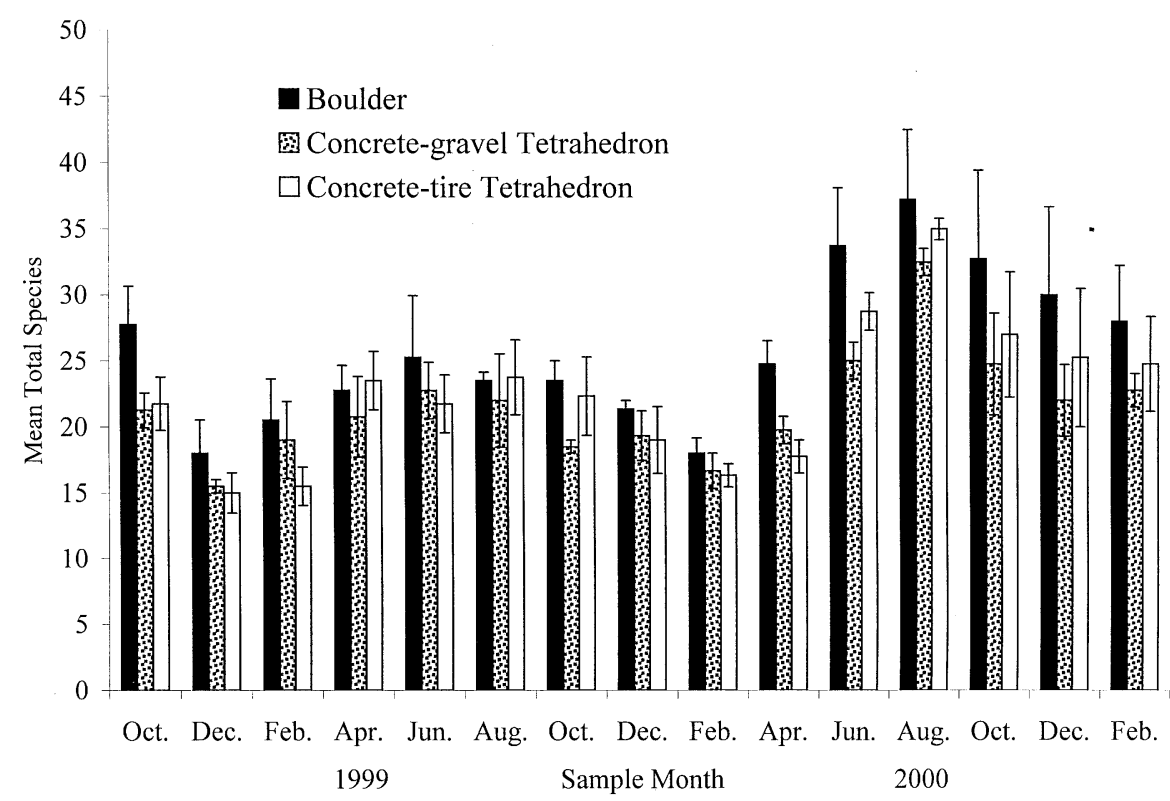

Fig. 3. Mean fish species (all sizes combined) on boulder, concrete-gravel, or concrete-tire reefs by month. Vertical lines represent one standard error of the mean. 


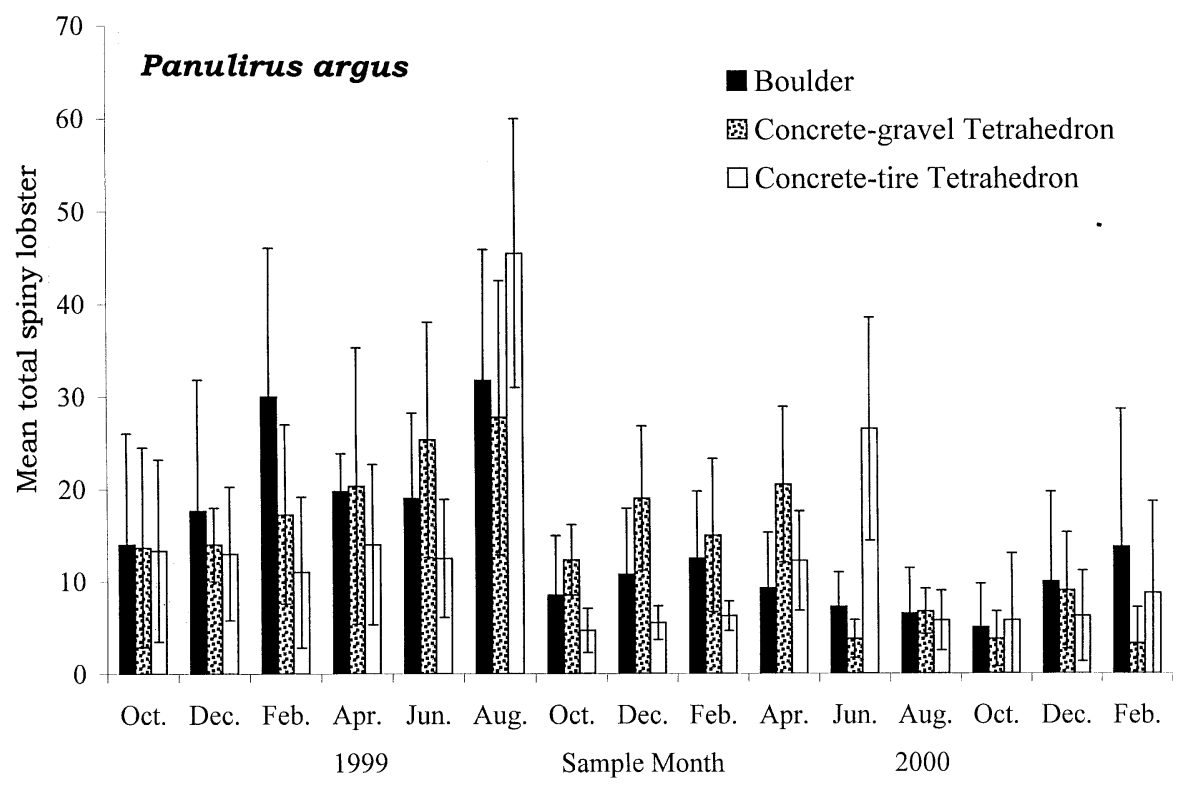

Fig. 4. Mean spiny lobster, Panulirus argus, abundance on boulder, concrete-gravel, or concrete-tire reefs by month. Vertical lines represent one standard error of the mean.

fish species versus a post-deployment mean of $6.6 \pm 1.3$. Pre- and post-deployment point counts on the reef sites also differed $(p<0.05$, Student's t-test) with a mean $15.5 \pm 8.7$ total fish per count pre-deployment versus a mean of $740.7 \pm 128$ fish post-deployment and a pre- deployment mean of $3.4 \pm 1.4$ fish species versus a post deployment mean of $29.2 \pm 1.8$ (although the counting methodologies, point-count and reef-count, differed the radius of each reef, and therefore the volume of each count, was less than the point-count, $6.5 \mathrm{~m}$ maximum versus $7.5 \mathrm{~m}$, so any error would be in undercounting the post-deployment reef sites).

Due to the limited number of samples taken on the jetty, only a single pre- and single post-deployment count, no statistical evaluation of the differences between pre- and post-assemblages was performed. However, a simple comparison of pre- versus post-deployment counts associated with the jetty also indicated an increase (4) in the number of species post-deployment. The abundance data appeared to differ with a decrease in numbers. The survey yielded 6885 total fish pre-deployment on the jetty and 3803 total fish post-deployment. Juvenile grunts (Haemulidae, $<5 \mathrm{~cm}$ TL) and tomtates (Haemulon aurolineatum, of all size classes) dominated these numbers (87\% of total). Excluding tomtates greater than $5 \mathrm{~cm}$ TL essentially eliminated the difference between pre- and post-deployment counts, the difference changed from 3082 to 2 . Interestingly, elimination of both juvenile grunts and tomtates from the jetty counts (pre and post deployment) showed an increase of 1 451 total fish from pre-deployment to post- deployment of the artificial reefs. We also estimated the total juvenile grunts and tomtates in the area (reef sites and jetty combined) pre- and post-deployment. The totals from all twelve reefs of tomtates and juvenile grunts from April 2000 were added to the totals counted on the jetty in May 2000 and compared to the totals of tomtates and juvenile grunts counted in May 1998. There was almost a 30\% increase (from 6039 to 9255 ) in tomtates and juvenile grunts combined after the 2-year presence of artificial reefs.

\section{Discussion}

\subsection{Temporal differences}

Total abundance and richness of fish fluctuated with season, increasing in the summer and decreasing in the winter. This trend is consistent with other similar local studies in the past Kruer and Causey, 1992; Cummings 1994:Gilliam_et_al__1995). Unlike the Gilliam_et_al_(1995 study that found 105 total species, there were 146 species of fish identified in this research. This could be due to differences in any number of factors including locality, changes in recruitment, currents, water quality, reef size, or sampling techniques.

\subsection{Abundance}

Similar to the preliminary study of Gilliam et_al_(1995) no significant differences were found in fish abundance between the differing concrete reefs. The limestone boulders, concrete-gravel tetrahedrons, and concrete-tire tetrahedrons all showed similar numbers in mean total fish. Likewise there was no significant difference amongst reef types for total fish biomass. There was no difference in spiny lobsters among the reef types. Likewise, a preliminary qualitative study did not detect a difference in other noncoral macroinvertebrates between reef types (unpublished). 


\subsection{Richness}

Species richness of fish differed depending on whether or not the data was scaled to reef size. If the data was left un-scaled, boulder reefs had more species than concrete reefs; conversely, boulders had fewer species if the data was scaled to reef size. Due to these conflicting results, a Bray-Curtis dissimilarity index with MDS ordination was performed to look for clustering of particular reef types due to similar fish assemblages. The seemingly random scattering of points on the MDS plot showed no correlation between fish assemblages and reef substrate materials. This leads us to conclude there is no difference in mean richness between reef substrate types.

\subsection{Aggregation versus production}

The dramatic increases in fish richness and abundance at the reef sites between pre- and post-deployment are not surprising (Bohnsack, 1989). However, the results from the stationary point counts and the jetty counts also show an increase in fish abundance and richness two years after artificial reef deployment on the natural, closely surrounding hard bottom area and (excluding haemulids) the jetty. The lower numbers of tomtates and juvenile grunts on the jetty post-deployment could be attributed to migration from the jetty to the nearby artificial reefs. However, the $30 \%$ increase between pre- and post-deployment in total tomtates and juvenile grunts on the jetty and reef sites combined would contradict such a hypothesis. While the point-count survey statistically shows a positive relationship between the addition of artificial substrate and an increase of fish abundance and species richness on the natural surrounding habitat, the jetty counts are not statistically comparable. Therefore, it is difficult to say for certain whether the results from the jetty counts are representative of average populations or if they reflect the variability inherent in many assessment techniques, e.g. circadian patterns, patchiness, visibility, etc. Likewise, it can be legitimately questioned if 12 point-counts on the natural hard bottom are sufficient to accurately depict resident populations. However, the results from the jetty counts are consistent with the results of the statistically tested point counts on the nearby hard bottom and the reef sites. These results argue against simple aggregation; the artificial reefs appear to have significantly enhanced the productivity of fish in their immediate area.

\section{Conclusion}

Many factors affect the floral and faunal assemblages on artificial reefs including reef design, depth, latitude, locality, salinity, etc. Bohnsack et al_ 1991) This study attempted to maintain consistency between some of these factors in order to reduce confounding variables affecting the results and yielding misleading interpretations of faunal preferences for reef construction materials. The assemblages of fish were comparable between reefs because they were deployed in the same area at the same time and depth with similar design. This study noted seasonal changes within the fish populations over the two-year study, however, after statistical analysis, the conclusion is there are no apparent differences among the three reef types.

During the course of this two-year study, the reef site has undergone extensive faunal enhancement due to the addition of these reefs. Pre-deployment surveys showed a sandy bottom area with a paucity of fauna. Conversely, the area today (two years postdeployment) contains at least 146 species of fish including many commercially and economically valuable species such as large tarpon, grouper, snapper, triggerfish, spiny lobster, bait fish, butterflyfish, etc. The pre- and post-deployment fish counts indicate this enhancement was not accomplished at the expense of immediately neighboring populations. As with any management tool, there must be caution when introducing new materials and artificial reef designs into an area. Different results are achieved using the same reef design at different depths or latitudes Sherman et al, 2001. However, indications from this study are that concrete-tire and concrete-gravel tetrahedrons are stable and can be used as effectively as limestone boulders for artificial reefs to enhance fish abundance and richness.

\section{Acknowledgements}

This project was funded by the City of Miami Beach. David Gilliam and Robin Sherman as well as Paul Arena, Brian Ettinger, Dan Fahy, Lance Jordan, and a number of other Nova Southeastern University (NSU) graduate students provided technical assistance with fish counts and diving. Charles Messing (NSU) provided essential aid in invertebrate identification.

\section{References}

Anderson, M.J., 1996. A chemical cue induces settlement of Sydney rock oysters, Saccostrea commercialis, in the laboratory and in the field. Biol. Bull. Mar. Lab. Woods Hole 190, 350-358.

Anderson, M.J., Underwood, A.J., 1994. Effects of substratum on the recruitment and development of an intertidal estuarine fouling assemblage. J. Exp. Mar. Biol. Sci. 184, 217-236.

Bohnsack, J.A., 1989. Are high densities of fish at artificial reefs the result of habitat limitation or behavioral preference? Bull. Mar. Sci. 44, 631-645.

Bohnsack, J.A., Bannerot, S.P., 1986. A stationary visual census technique for quantitatively assessing community structure of coral reef fishes. NOAA Techn. Rep. NMFS 41, 18.

Bohnsack, J.A., Harper, D.E., 1998. Length-weight relationships of selected marine reef fishes from southeastern United States and the Caribbean. NOAA Technical Memorandum NMFS SEFC-215, 31.

Bohnsack, J.A., Johnson, D.L., Ambrose, R.F., 1991. Ecology of artificial reef habitats and fishes. In: Seaman Jr, W., Sprague, L.M (Eds.), 
Artificial habitats for marine and freshwater fisheries. Academic Press. San Diego, California, pp. 61-107.

Bohnsack, J.A., Sutherland, D.L., 1985. Artificial reef research: A review with recommendations for future priorities. Bull. Mar. Sci. 37, 11-39.

Bortone, S.A., Van Orman, D., 1985. Factors controlling optimal biological productivity on artificial reefs. Bull. Mar. Sci. 37, 396-402.

Carr, M.H., Hixon, M.A., 1997. Artificial reefs: the importance of comparisons with natural reefs. Fisheries: spec. issue on artificial reef management 22, 28-33.

Chin, G.D., Simmons, R., 1994. Evaluating artificial reefs at Parteau Cove Provincial Park. Bull. Mar. Sci. 55, 1332.

Collins, K.J., Jensen, A.C., Mallinson, J.J., Mudge, S.M., Roenelle, V., Russel, A., Smith, I.P., 1999. Environmental impact assessment of a scrap tyre artificial reef. Proceedings from $7^{\text {th }}$ International Conference on Artificial Reefs and Related Aquatic Habitats, San Remo, Italy. pp. 356-363.

Cummings, S.L., 1994. Colonization of a nearshore artificial reef at Boca Raton, (Palm Beach County). Florida. Bull. Mar. Sci. 55, 1193-1215.

Day, K.E., Holtze, K.E., Metcalfe-Smith, J.L., Bishop, C.T., Dutka, B.J., 1993. Toxicity of leachate from automobile tires to aquatic biota. Chemosphere 27, 665-675.

Downing, N.R., El-Zahr, C., McClure, R., 1985. Artificial reefs in Kuwait, northern Arabian Gulf. Bull. Mar. Sci. 37, 157-178.

Evans, J.J., 1997. Rubber tire leachates in the aquatic environment. Rev. Environ. Contam. Toxicol. 151, 67-115.

Evans, J.J., Shoemaker, C.A., Klesius, P.H., 2000. In vivo and in vitro effects of benzothiazole on sheepshead minnow (Cyprinodon variegatus. Mar. Environ. Res. 50, 57-261.

Field, J.G., Clarke, K.R., Warwick, R.M., 1982. A practical strategy for analyzing mutlispecies distribution patterns. Mar. Ecol. Prog. Ser. 8, $37-52$.

Figley, W., 1994. Developing public and private tire reef unit construction facilities. Bull. Mar. Sci. 55, 1334.

Fitzhardinge, R.C., Bailey-Brock, J.H., 1989. Colonization of artificial reef materials by corals and other sessile organisms. Bull. Mar. Sci. 44, 567-579.

Gilliam, D., Banks, K., Spieler, R.E., 1995. Evaluation of a tire-concrete aggregate for artificial reef construction. ECOSET. Proc. 1, 345-350.

Henriquez, P., Badalamenti, F., Chemello, R., D’Anna, G., Riggio, S., 1999. Are artificial reefs related to adjacent natural rocky areas? A mollusc case study in the Gulf of Castellammare (NW Sicily). Proceedings from $7^{\text {th }}$ International Conference on Artificial Reefs and Related Aquatic Habitats, San Remo, Italy.

Kruer, C.R., Causey, L.G., 1992. The use of large artificial reefs to enhance fish populations at different depths in the Florida Keys. Florida Keys Artificial Reef Association, Inc.

Meier, M.H., Eskridge, J.B., 1994. Made in Virginia—the past, present, and future of Virginia's artificial reef program. Bull. Mar. Sci. 55, 1346.

Miller, M.W., Barimo, J., 2001. Assessment of juvenile coral populations at two coral reef restoration sites in the Florida Keys National Marine Sanctuary: indicators of success? Bull. Mar. Sci. 69, 395-405.

Murphey, S.W., Gregg, K.L., 1994. North Carolina artificial reef program. Bull. Mar. Sci. 55, 1347.

Myatt, D.O., Myatt, E.N., Figley, W.K., 1989. New Jersey tire reef Stability Study. Bull. Mar. Sci. 44, 807-817.

Seaman Jr, W., 2000. Artificial reef evaluation with application to natural marine habitats. CRC Press, Boca Raton.

Seaman Jr, W., Jensen, A., 2000. Purposes and practices of artificial reef evaluation. In: Seaman Jr, W (Ed.), Artificial reef evaluation with application to natural marine habitats. CRC Press, Boca Raton, Florida, pp. 1-19.

Seaman Jr, W., Sprague, L.M., 1991. Artificial habitat practices in aquatic systems. In: Seaman Jr, W., Sprague, L.M (Eds.), Artificial Habitats for Marine and Freshwater Fisheries. Academic Press, San Diego, California, pp. 1-29.

Sherman, R.L., Gilliam, D.S., Spieler, R.E., 2001. Site dependent differences in artificial reef function: implications for coral reef restoration. Bull. Mar. Sci. 69, 1053-1056.

Stone, R.B., Sprague, L.M., McGurrin, J.M., Seaman Jr, W., 1991. Artificial habitats of the world: synopsis and major trends. In: Seaman Jr, W., Sprague, L.M (Eds.), Artificial Habitats for Marine and Freshwater Fisheries. Academic Press, San Diego, California, pp. 31-60.

Suprenant, B., 1991. Designing concrete for exposure to seawater. Concrete Construction Magazine, 814-816.

Tolley, H.A., 1981. Tires as artificial reef material. Artificial Reefs: Proceedings of a Conference held Sept. 13-15, 1979 in Daytona Beach, FL. Rep. FL. Sea Grant Program, 86-88. 